\title{
PROSES PUBLIKASI HUMAS BADAN NASIONAL PENGELOLA PERBATASAN PADA AKUN MEDIA SOSIAL INSTAGRAM
}

TRI BASKARA \& MENATI FAJAR RIZKI

Fakultas IImu Sosial, Universitas Negeri Jakarta

Jl. Rawamangun Muka, Rawamangun, Kec. Pulo Gadung, Kota Jakarta Timur Email: mfajarrizki@unj.ac.id

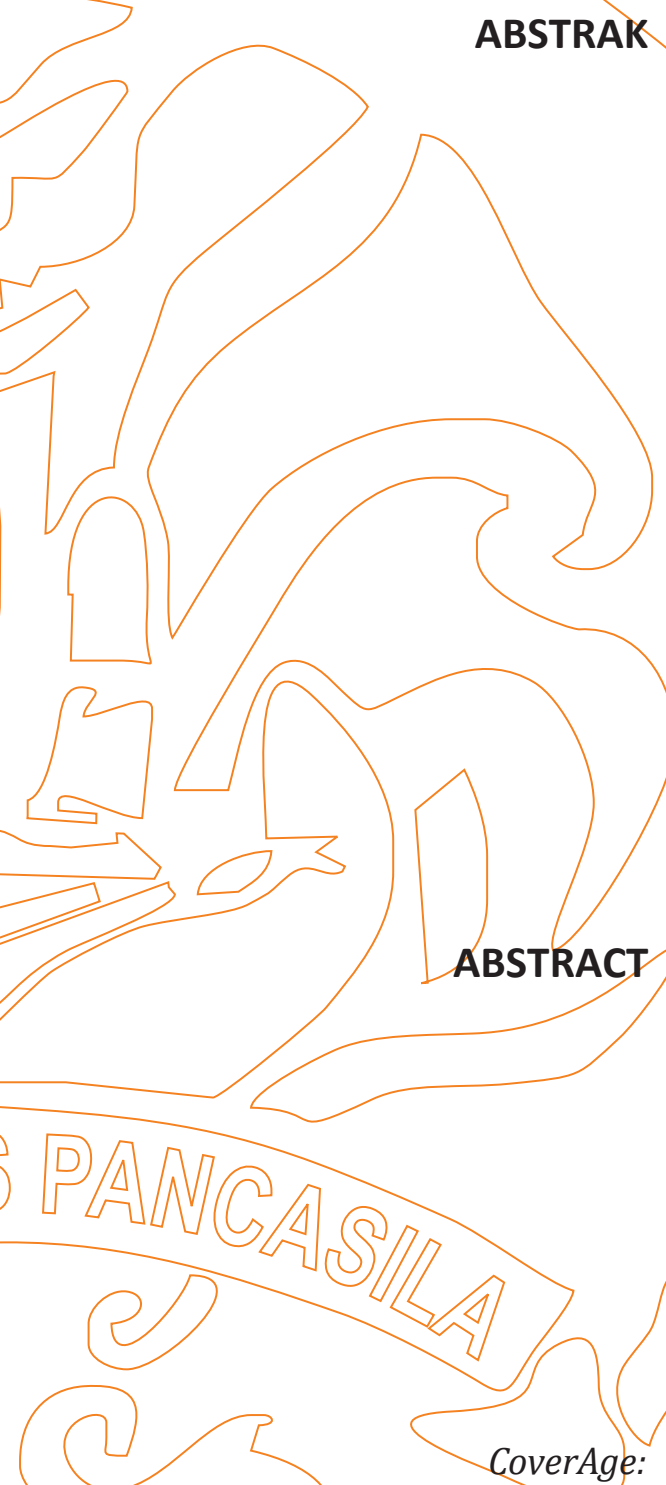
Journal of Strategic

Communication

Vol. 10, No. 1, Hal. 19-26.

September 2019

Fakultas Ilmu Komunikasi, Universitas Pancasila
Badan Nasional Pengelola Perbatasan Republik Indonesia sebagai lembaga pemerintah memiliki tugas untuk mengelola batas wilayah Negara. Terkait dengan perbatasan negara, informasi sangat dibutuhkan oleh warga negara Indonesia untuk mengetahui tentang apa saja wilayah perbatasan negara Indonesia dan bagaimana kondisi wilayah perbatasan. Humas BNPP merupakan divisi terdepan untuk menginformasikan hal yang berkaitan dengan Keterbukaan informasi BNPP. Tujuan dari penelitian ini untuk mengetahui proses publikasi oleh divisi Humas BNPP pada akun Instagram serta hambatannya. Penelitian ini menggunakan Teori P.O.A.C dan media baku. Penelitian ini menggunakan pendekatan kualitatif dengan studi deskriptif pada akun Instagram BNPP. Penelitian ini dilakukan di Kantor humas BNPP dengan satu Key Informan dan dua informan. Hasil penelitian ini menunjukan bahwa dalam proses publikasi humas BNPP di instagram mengalami hambatan. Pada bagian Perencanaan yaitu Manusia (SDM) yang kurang, lalu indikator dari Pengorganisasian yaitu teknologi sebagai penyediaan tempat kerja dan teknologi pendukung pembuatan publikasi yang masih kurang, lalu hambatan terakhir adalah Pengarahan di mana pada hasil penelitian ini hambatannya terletak pada Komunikasi Vertikal antara Pimpinan dan Staff dalam proses publikasinya. Kesimpulan penelitian ini yaitu penggunaan media instagram dalam publikasi sudah cukup efektif melihat perkembangan zaman sehingga tepat sasaran ke masyarakat.

Kata kunci: Humas BNPP, Instagram, publikasi

The National Agency for Border Management of the Republic of Indonesia as a government agency has the duty to manage the country's territorial borders. Regarding the country's borders, information is needed by Indonesian citizens to find out about what the country's borders are and what the conditions are BNPP Public Relations is/the leading division to inform matters relating to the Disclosure of BNPP information. The purpose of this study was to determine the publication process by the BNPP Public Relations division on Instagram accounts and their obstacles. This research uses P.O.A.C theory and new media. This study uses a qualitative approach with a descriptive study on BNPP's Instagram account. This research was conducted at the BNPP public relations office with one Key Informant and two informants. The results of this study indicate that the public relations process of BNPP on Instagram faces obstacles. In the Planning section that is Human $(H R)$ is lacking, then the indicators of Organizing namely Technology as the supply of workplaces and supporting technology for making publications are still/acking, then the last obstacle is Direction in which the results of this study the obstacle lies in Vertical Communication between Leaders and Staff in the process of publication. The conclusion of this research is the use of Instagram media in publications is effective enough to see the times so that it is right on target to the community. 


\section{PENDAHULUAN}

Badan Nasional Pengelola Perbatasan Republik Indonesia merupakan lembaga pemerintah yang mempunyai tugas untuk mengelola batas wilayah negara. Mulai dari segi lintas batas dengan negara tetangga, pengelolaan potensi serta pembangunan infrastuktur dan meningkatkan kesejahteraan masyarakat di kawasan perbatasan. Peraturan Presiden Nomor 12 Tahun 2012 tentang Badan Nasional Pengelola Perbatasan (BNPP) mengemukakan bahwa badan ini merupakan lembaga nonstruktural yang dipimpin oleh seorang kepala badan yang berkedudukan di bawah dan bertanggung jawab kepada presiden (Perbatasan, 2019).

AdanyaBNPPdiperlukanuntukpengelolaan batas wilayah negara Indonesia, serta menginformasikan ke masyarakat batas-batas negara, pentingnya memahami kondisi dan bentuk batas negara, karena setiap negara di dunia memiliki batas wilayah negara yang bertujuan untuk menandai bahwa suatu wilayah masih dalam teritori negara kita atau sudah wilayah negara tetangga. Bentuk dari perbatasan suatu wilayah sangat beragam, seperti perbatasan dalam bentuk Gapura, Tugu, berupa sungai, Laut, Pagar dan sebagainya.

Pemahaman berkenaan dengan perbatasan negara masih sangat minim dirasakan oleh masyarakat. Pentingnya mengetahui batas negara, bagaimana cara memperlakukan patok batas negara, contohnya saja isu patok batas di beberapa titik sengketa Malaysia. Disampaikan oleh Mayor Jenderal (Mayjen) (Purn) Deddy Hadria (Tim Ahli BNPP), berkenaan dengan perbatasan negara, beliau mengingatkan masyarakat agak setidaknya selalu berhati-hati dalam 'memperlakukan' patok batas. Yang paling aman adalah kalau ada kerusakan atau hilang, dilaporkan saja. Bisa kepada pihak kecamatan setempat, Polsek (Kepolisian Sektor) atau Pamtas (Pasukan Pengamanan Perbatasan (Pamtas) (Hadria, 2017).

Pemahaman perbatasan negara serta pengelolaan yang dilakukan oleh BNPP erat kaitannya dengan informasi yang dikeluarkan dan disampaikan kepada publik. Kegiatan tersebut dilakukan oleh biro keuangan umum dan humas yang dimiliki oleh BNPP. Biro ini membawahi biro humas yang bertugas untuk menginformasikan semua kegiatan BNPP serta wawasan tentang batas negara kepada masyarakat. Humas BNPP merupakan bidang penting yang bertujuan untuk mempublikasikan dan menginformasikan berkenaan kegiatan ataupun Informasi mengenai kebijakan-kebijakan, rencana-rencana, serta hasil-hasil kerja BNPP serta memberikan pengertian kepada masyarakat tentang peraturan dan perundang-undangan dan segala sesuatu yang berpengaruh terhadap kehidupan masyarakat.

Humas BNPP harus dapat menjangkau seluruh masyarakat dari sabang sampai merauke dalam memberikan informasi. Media tercepat dan terpopuer saat ini adalah media sosial Instagram. Humas BNPP menggunakan Instagram karena di era sekarang, media sosial yang paling digemari adalah Instagram didapat dari data dan fakta statistik dari total populasi Indonesia sebanyak 265,4 juta jiwa, pengguna aktif media sosialnya mencapai 130 juta dengan penetrasi 49 persen. Dari hasil survei WeAreSocial dan Hootsuite kembali, Instagram merupakan platform media sosial dengan jumlah pengguna terbanyak ke tujuh di dunia dan terbesar ke empat di Indonesia (Social, 2019). Sehingga diharapkan dapat mengjangkau seluruh masyarakat, baik yang muda hingga usia dewasa.

Kegiatan ini berkaitan dengan kegiatan humas yaitu publikasi. Menurut Kriyantono, pada buku Public Relations Writing, publikasi adalah kegiatan menyampaikan atau menyebarluaskan informasi. Publikasi Berasal dari kata "publicare" yang artinya "untuk umum". Jadi publikasi adalah kegiatan mengenalkan perusahaan sehingga umum atau publik dan masyarakat dapat mengenalnya (Kriyantono, 2016). Kegiatan publikasi harus dilakukan secara berkala agar mendapat atensi dari masyarakat.

Melihat kegiatan publikasi BNPP yang dilakukan melalui media sosial Instagram, kurang konsisten dalam menginfokan. Jarak mem-publish konten untuk memenuhi wawasan masyarakat terkait perbatasan negara dirasa masih tidak tepat. Konten dipublish dua minggu sekali, sebulan sekali, bahkan terkadang konten yang di-upload adalah ucapan hari besar negara, informasi tentang batas negara masih terlalu sedikit.

Hal ini yang menarik penulis dalam melakukan penelitian berkenaan dengan pengelolaan Instagram BNPP. Dengan hadirnya new media, seharusnya dapat menunjang kemudahan pemberian informasi. Maka dari itu penulis merumuskan penelitian "Proses Publikasi Humas Badan Nasional Pengelola Perbatasan Pada Akun Media Sosial Instagram". Tujuan dari penelitian ini adalah untuk mengetahui proses publikasi yang dilakukan oleh Divisi Humas BNPP, alur informasinya, serta apa saja hambatan yang didapatkan ketika proses publikasi pada media sosial Instagram. 


\section{TINJAUAN PUSTAKA}

\section{Publikasi Humas}

Publikasi menurut Philip dan Herbert $M$. Baus dalam buku Perceptions for Communications adalah tugas public relations dalam menceritakan atau menyampaikan sebanyak mungkin pesan atau informasi mengenai kegiatan perusahaan kepada masyarakat luas, dengan kata lain publikasi merupakan kegiatan terpenting dan menjadi ujung tombak dari kegiatan humas (Ruslan, 2018).

Sedangkan menurut liliweri, publikasi merupakan proses membuat konten tertentu agar diketahui publik, untuk distribusi teks atau gambar di atas kertas, atau penempatan konten pada website. Kata publikasi berarti tindakan penerbitan berarti setiap tulisan, buku, majalah, jurnal ilmiah, surat kabar yang diterbitkan dalam setiap situs web (Liliweri, 2011). Publikasi merupakan salah satu kegiatan humas untuk menginfokan kepada publiknya mengenai info terkait BNPP, apa yang sedang dilakukan oleh BNPP, bagaimana cara BNPP mengelola perbatasan, bagaimana sosialisasi yang dilakukan ke daerah-daerah.

Menurut Fariani dan Aryanto terdapat dua jenis publikasi menurut target komunikasinya, yaitu publikasi internal dan publikasi eksternal (Fariani, 2013). Publikasi internal ditujukan kepada pihakpihak dalam BNPP. Sedangkan pada publikasi eksternal ditujukan kepada khalayak luar BNPP. Komunikasi yang dilakukan lebih bersifat kompleks jika dibandingkan kepada pihak internal, karenanya perlu dilakukan perencanaan yang baik ketika hendak melakukan publikasi kepada masyarakat Indonesia.

\section{New Media}

Meyrowitz mengungkapkan bahwa lingkungan media baru atau dikenal dengan cyberspace telah membawa tawaran pemikiran baru terhadap riset media yang tidak hanya berfokus pada pesan semata,tetapi mulai melibatkan teknologi komunikasi itu sendiri yang secara langsung maupun tidak, memberikan fakta bahwa perangkat komunikasi berteknologi itu merupakan salah satu bentuk atau tipe dari lingkungan sosial (Nasrullah, 2016). Media baru juga termasuk di dalamnya media sebagai sebuah saluran yang digunakan seperti komputer, telepon genggam, dan smart TV.

Media baru yang digunakan oleh Humas BNPP dalam menyebarkan informasi adalah media sebagai perangkat teknologi komunikasi yang perangkatnya memiliki ciri mirip dengan lainnya dan memiliki karakter digitalisasi bagi penggunanya berkomunikasi (Mcquail, 2010). Media baru yang digunakan dalam penelitian ini adalah akun media sosial Instagram BNPP dengan nama akun bnpp_ri.

Menurut Dennis Mcquail, media baru jika dilihat dari perspektif penggunanya yaitu: (1) Interaktivitas media baru membuat feedback antara kedua belah pihak tidak ada delay. (2) Sosiabilitas, media baru mempunyai kemampuan untuk menghubungkan secara maya individu dengan individu lain. (3) Media Richness, mempunyai kemampuan untuk mewakili berbagai bentuk simbol baik itu simbol verbal ataupun non verbal. (4) Otonomi, Individu yang menggunakan media baru, mempunyai kekuasaan lebih besar dalam mengendalikan informasi baik itu informasi yang disampaikan oleh individu tersebut ataupun informasi darifeedback yang mereka terima. (5) Playfulness, media baru mempunyai kegunaan sebagai sarana mencari hiburan dan kesenangan bagi penggunanya. (6) Privacy, media baru mempunyai tingkat kerahasiaan yang tinggi, dimana tingkat kebebasan individu berinteraksi dengan media intens namun tidak banyak orang terlibat atau mengetahui. (7) Personalism, penggunaan media baru dan isi media baru bersifat personal dan unik, tergantung pada kepribadian dan individu yang menggunakan media baru tersebut (Sary, 2013).

\section{Teori P.O.A.C}

Teori yang dlgunakan pada penelitian ini adalah teori dari George R. Terry yaitu planning, organizing, actuating, dan controlling (Sukarna, 2011). Teori POAC tersebut selanjutnya akan digunakan penulis untuk menjadi dasar dalam melakukan penelitian. Penulis menggunakan teori POAC karena fungsi-fungsi di dalamnya mampu melihat kondisi yang terjadi pada Humas Badan Nasional Pengelola Perbatasan dalam proses publikasinya khususnya publikasi untuk media sosial Instagram.

Planning (perencanaan) ialah pemilihan dan penghubungan fakta-fakta serta pembuatan dan penggunaan perkiraan-perkiraan asumsiasumsi untuk masa yang akan datang dengan jalan menggambarkan dan merumuskan kegiatan-kegiatan yang diperlukanuntukmencapai hasil yang diinginkan. Organizing (pengorganisasian) adalah penentuan, pengelompokkan dan penyusunan macam-macam kegiatan yang diperlukan untuk mencapai tujuan, penempatan orang-orang(pegawai), terhadap kegiatan-kegiatan ini, penyediaan faktor faktor fisik yang cocok bagi keperluan kerja dan penunjukkan 
hubungan wewenang yang pelaksabaan setiap kegiatan yang diharapkan.

Actuating (pergerakan) adalah membangkitkan dan mendorong semua anggota kelompok agar berkehendak dan berusaha dengan keras untuk mencapai tujuan dengan ikhlas serta serasi dengan perencanaan dan usaha-usaha pengorganisasian dari pihak pimpinan. Controlling (pengawasan) dapat dirumuskan sebagai proses penentuan apa yang harus dicapai, yaitu standar apa yang sedang dilakukan yaitu pelaksanaan, menilai pelaksanaan dan bilamana perlu melakukan perbaikan perbaikan, sehingga pelaksanaan sesuai dengan rencana, yaitu selaras dengan standar.

\section{METODE}

Penelitian yang digunakan adalah penelitian kualitatif merupakan jenis penelitian yang menghasilkan penemuan penemuan yang tidak dapat dicapai dengan menggunakan prosedur statistik atau cara kuantitifikasi lainnya, yang dapat digunakan untuk penelitian kehidupan masyatakat, sejarah, tingkah lakum fungsional organisasi, peristiwa tertentu, pergerakan pergerakan sosialm dan hubungan kekerabatan dalam kekeluargaan (Ruslan, 2017).

Sedangkan metode pengumpulan data yang penulis gunakan dalam penelitian ini menggunakan 2 cara yaitu melalui Wawancara mendalam dan Observasi. Wawancara mendalam adalah percakapan dua arah dalam suasana kesetaraan, akrab dan informal yang bersifat luwes,terbuka, tidak terstruktur, dan tidak baku. Intinya adalah pertemuan berulang kali secara langsung antara peneliti dan subjek penelitian (Sugiyono, 2017). Wawancara mendalam dinilai cukup efektif untuk metode pengumpulan data penelitian penulis saat ini karena hal hal yang berkaitan tentang media sosial di intagram BNPP dapat digali dan ditanyakan secara mendalam kepada para informan.

Subjek dalam penelitian ini ialah pihak Bidang Humas Badan Nasional Pengelola Perbatasan, yang terbagi atas Informan Kunci (Key Informan) dan Informan Pendukung. Kutipan pengertian dari hendarsono dalam buku Metode Penelitian Sosial Suyanto menyebutkan bahwa, dalam penelitian kualitatif terdapat 3 jenis informan yaitu

1. Informan kunci (Key Informan) yaitu mereka yang mengetahui dan memiliki berbagai informasi pokok yang diperlukan dalam penelitian.
2. Informan utama, yaitu mereka yang terlibat secara langsung dalam interaksi sosial yang diteliti.

3. Informan tambahan, yaitu mereka yang dapat memberikan informasi walaupun tidak langsung terlibat dalam interaksi sosial yang diteliti (Suyanto, 2015).

Dari uraian tersebut, pada penelitian ini penulis mendapatkan beberapa informan, informan kunci (Key Informan) dalam penelitian ini adalah sebagai berikut:

Tabel 1.

Key Informan Penelitian

\begin{tabular}{|c|c|c|}
\hline No & Nama & Keterangan \\
\hline 1 & $\begin{array}{c}\text { Bpk. Andri Indrawan, } \\
\text { S.Sos,M.Si }\end{array}$ & $\begin{array}{c}\text { Kepala Bagian } \\
\text { Hubungan } \\
\end{array}$ \\
& & $\begin{array}{c}\text { masyarakat dan TU } \\
\text { Pimpinan }\end{array}$ \\
\hline
\end{tabular}

Tabel 2.

Informan Penelitian

\begin{tabular}{|c|l|l|}
\hline No & \multicolumn{1}{|c|}{ Nama } & \multicolumn{1}{c|}{ Keterangan } \\
\hline 1 & $\begin{array}{l}\text { Caesario } \\
\text { Ferdinand } \\
\text { Joshua }\end{array}$ & $\begin{array}{l}\text { Staff Biro Keuangan,Umum, } \\
\text { dan Humas, serta Admin Akun } \\
\text { Instagram BNPP }\end{array}$ \\
\hline 2 & $\begin{array}{l}\text { Faizah } \\
\text { Fatmala }\end{array}$ & $\begin{array}{l}\text { Staff pada Biro Keuangan, } \\
\text { Umum dan Hubungan } \\
\text { Masyarakat, creative design } \\
\text { instagram BNPP }\end{array}$ \\
\hline
\end{tabular}

Lokasi penelitian dilakukan di Kantor Badan Nasional Pengelola Perbatasan, Jl. Kebon Sirih No. 31A, RT.1/RW.5, Kebon Sirih, Menteng, Kota Jakarta Pusat, DKI Jakarta Kode Pos 10340. Serta akun Instagram BNPP yaitu bnpp_ri.

\section{HASIL DAN PEMBAHASAN}

Badan Nasional Pengelola Perbatasan sebagai lembaga non kementrian memiliki peran penting terhadap kawasan perbatasan, kebijakan pimpinan mengenai wilayah perbatasan terlebih dengan informasi yang harus disampaikan kepada publiknya, maka dari itu penulis menggambarkan definisi humas menurut Bpk. Andri Indrawan selaku kepala Humas dan TU pimpinan Badan Nasional Pengelola Perbatasan: 
"Humas sendiri kan kepanjangan dari hubungan masyarakat, sebuah fungsi manajemen dalam melaksanakan komunikasi baik ke dalam dan masyarakat luas, sehingga apa yang bisa membangun citra lembaga lebih baik dan positif, membangun persepsi pubilk yang favorable dan juga membangun trust/ kepercayaan terhadap suatu lembaga, makanya humas sangat penting dalam artian menjembatani lembaga dengan publik ataupun khalayaknya" (Wawancara Key Informan, 28 Juni 2019).

Berkenaan dengan peran dan fungsi humas yang dapat ditarik dari hasil penelitian yaitu manajemen yang seharusnya berada pada level atas yang memiliki peran membina hubungan internal lembaga di Badan Nasional Pegelola Perbatasan dalam upaya memberikan informasi kepada pimpinan lembaga terhadap pembuatan kebijakan dan keputusan, lalu memberikan solusi terhadap permasalahan informasi yang berada pada lembaga terhadap publiknya.

Humas Badan Nasional Pengelola Perbatasan memiliki kewenangan dalam mempublikasikan informasi mengenai sebuah kebijakan pimpinan lembaga, kegiatan yang ada di dalamnya serta informasi penting mengenai perkembangan wilayah kawasan perbatasan indonesia. Kegiatan publikasi Humas BNPP yaitu menyebarluaskan informasi kepada khalayak/publik dengan intens secara menarik dan dengan komunikasi secara efektif efisien kemudian apa yang diharapkan dari isi pesan itu dapat disampaikan dan dapat ditindaklanjuti oleh khalayak sesuai yang diharapkan.

\section{New Media Sebagai Publikasi}

(1) Interaksi source \& receiver, pada hasil temuan pertama yang penulis temukan dari hasil observasi pada tanggal 2 agustus 2019, pada akun instagram Badan Nasional Pengelola Perbatasan Republik Indonesia jika dilihat dari interaksi antara Source/sumber (instagram Badan Nasional Pengelola Perbatasan) dengan receiver/ penerima (followers akun instagram Badan Nasional Pengelola Perbatasan) serta adanya Direct Message pengguna aktif intagram. (2) Sosiabilitas, media baru mempunyai kemampuan untuk menghubungkan secara maya individu dengan individu lain sehingga terbentuknya sebuah kehidupan sosial, di mana tidak dibutuhkannya kehadiran fisik dari individu-individu yang terlibat disebut dengan kehadiran sosial atau sosiabilitas. Publikasi humas di akun instagram Badan Nasional Pengelola Perbatasan, sosiabilitas itu muncul dengan mention atau tag antar lembaga Kementrian yang berada di Indonesia. Contoh tag Kemendagri kepada akun IG BNPP.

(3) Media Richness, pada konten publikasi humas Badan Nasional Pengelola Perbatasan di instagram mendapatkan timbal balik dari salah satu pengguna atau penerima pesan tersebut, seperti yang diunggah pada akun instagram @aisyahdianm, pada akun instagram tersebut penerima pesan memposting kembali kegiatan lembaga Badan Nasional Pengelola Perbatasan yang telah di upload atau unggah di akun instagram Badan Nasional Pengelola Perbatasan. (4) Playfullnes, media baru selain memudahkan sebuah informasi sampai kepada receiver atau penerima pesan konten itu. Selanjutnya Pada temuan penulis selanjutnya dalam publikasinya di akun instagram humas Badan Nasional Pengelola Perbatasan telah berencana dalam berinovasi dalam membuat konten agar terlihat lebih menarik, salah satunya adalah konten Dilan 1990 dengan quote-nya Dilan 1990 itu yang "rindu itu berat, biar aku saja. Humas BNPP pernah mencoba membuat gambar dilan yang dari buku plus kita kasih siluetnya tugu pancasilanya di PLBN Entikong kita lalu diberi quotte "jaga perbatasan itu berat, biar kami saja".

(5) Privasi, publikasi untuk akun instagram Badan Nasional Pengelola Perbatasan bahwa tidak ada privasi untuk setiap konten yang di informasikan di akun instagram Badan Nasional Pengelola Perbatasan, hal itu ditunjukan dengan adanya temuan yang menyebutkan bahwa untuk setiap sosmed yang di publikasikan tidak di Hide terhadap orang lain ataupun penerima pesan itu sendiri. (6) Personalisasi, publikasi humas di instagram Badan Nasional Pengelola Perbatasan bahwa humas dalam menginformasikan kegiatan di instagramnya dengan informasi yang unik, salah satunya adalah menampilkan potensi wilayah yang letaknya di wilayah perbatasan negara Indonesia.

Pada penelitian kali ini penulis menggunakan Teori P.O.A.C (Planning, Organizing, Actuating, Controlling ) yang dikemukakan oleh ahli George R. Terry dalam upaya menggambarkan dan mengupas permasalahan yang terdapat pada hasil penelitian yang penulis temukan pada saat wawancara mendalam dan observasi pada Proses Publikasi Humas Badan Nasional Pengelola Perbatasan. Pembahasan ini diuraikan secara sistematis perindikator yang penulis temukan berdasarkan hasil wawancara mendalam dan observasi.

Planning, langkah perencanaan merupakan langkah paling awal dalam proses publikasi. Humas 
BNPP terlebih dahulu menyiapkan materi publikasi apa saja yang akan diolah dan nantinya akan diunggah pada Instagram. Lalu setelah menyiapkan materi yang akan dibuat tahapan selanjutnya yaitu pembuatan konten yang dilakukan oleh tim kreatif humas BNPP. Pada proses awal pembagian pembuatan konten oleh tim kreatif, Humas Badan Nasional Pengelola Perbatasan masih kekurangan Sumber Daya Manusia sebagai penunjang pelaksanaan tugas Publikasi humas BNPP. Hanya ada sedikit tim kreatif sehingga pembuatan konten dipaksakan harus maksimal dengan jumlah tim yang sangat sedikit.

Organizing, dalam melakukan pengorganisasiannya, humas BNPP dalam proses publikasinya masih memiliki kekurangan pada faktor fisik yang menjadi keperluan Kerja, di antaranya adalah pada teknologi yang digunakannya masih kurang, hal tersebut disampaikan oleh Kak fay sebagai Creative Design publikasi humas BNPP selaku pengelola Aktif akun Instagram BNPP. Dalam suatu insdustri yang menggunakan mesin mesin jumlah hasil produksi tergantung pada mesin yang dipakai. Humas BNPP masih kekurangan komputer sebagai alat pendukung dalam pembuatan konten publikasi untuk instagram, lalu kamera yang digunakan untuk pendokumentasian acara, rapat dan kegiatan humas BNPP lainnya sebagai alat pendukung masih kurang memadai.

Untuk pengorganisasian dalam biro atau divisi, pada Sub Bagian Publikasi dan Dokumentasi, sub bagian ini dikhususkan untuk melakukan tugas yaitu menyebarluaskan publikasi dan informasi yang telah direncanakan melalui media sosial dan media cetak yang ada di internal BNPP. Selain itu juga ada Sub Bagian Protokol dan Kehumasan yang mengurusi tentang keprotokolan kegiatan humas baik internal maupun eksternal. Namun demikian, hal tersebut tetap secara Struktural Kepala Bagian Humas BNPP harus mengetahui mengenai perkembangan yang terjadi dari setiap Sub Bagian yang berada di bidang Humas BNPP.

Actuating, pada implementasinya dalam melakukan tugas dan fungsi humasnya, Kepala Humas Badan Nasional Pengelola Perabatasan membangun komunikasinya secara langsung kepada staffnya dan melalui tulisan melalui whatsapp group kepada Staff Humasnya terutama dalam membuat publikasi humasnya. Komunikasi yang dilakukan oleh Kepala humas bersifat direct maksudnya adalah arahan tersebut langsung mengarah kepada staff yang bersangkutan, jadi ketika sedang ada konten yang akan dibuat, biasanya Kepala humas langsung memberikan arahan kepada staffnya tidak melalui perantara, ini disebut sebagai komunikasi vertikal yaitu komunikasi yang dilakukan dalam internal organisasi antara atasan dengan bawahan atau sebaliknya dalam suasana formil.

Namun pada komunikasi vertikal secara tidak langsung tersebut justru menimbulkan masalah, yang dapat menghambat proses pembuatan publikasi humas BNPP. Seperti yang sudah disebutkan tentang pengertian komunikasi vertikal tersebut yaitu komunikasi yang dilakukan antara atasan dan bawahan, permasalahan yang timbul adalah ketika seorang Staff humas yang sedang melakukan proses pembuatan konten publikasi, permasalahan pertama yang muncul adalah terlalu lama dalam memberikan tanggapan/revisi kepada pembuat konten. Lalu permasalahan kedua yang bisa menjadi faktor penghambatnya yaitu birokrasi dalam melakukan komunikasinya, jadi ketika konten itu sudah selesai dirampungkan, pembuat konten harus berkoordinasi dengan eselon 3 sampai 1. Namun ketika konten tersebut baru sampai di eselon 3 dan revisi pada akhirnya konten tersebut belum bisa di ACC pada Eselon 1 dan pada akhirnya konten tersebut terhambat untuk dinaikkan pada akun Instagram BNPP.

Controlling, pada proses publikasi humas BNPP, cara yang digunakan dalam melakukan pengawasan/ pengendalian yaitu dengan pengendalian umpan balik (Post-Action Control). Pengendalian ini mengevaluasi hasil-hasil yang telah terjadi setelah suatu kegiatan selesai. Penyebab-penyebab kesalahan yang mungkin terjadi itu di tentukan dan kesalahan yang sudah ditentukan itu nantinya akan dapat digunakan untuk perencanaan pada masa yang akan dating. Hal tersebut diukur melalui controlling insight instagram Badan Nasional Pengelola Perbatasan dengan interval waktu 1 minggu 2 kali, yang dilakukan pada pagi dan sore hari, tugas tersebut biasanya dilakukan oleh pengelola aktif akun instagram BNPP agar mereka yang lebih paham mengenai tugas dan fungsinya.

Proses pelaksanaan pengendalian dapat dilakukan melalui beberapa tahapan. Tahapan tersebut merupakan rangkaian proses yang dilakukan dalam pengendalian. Menurut $\mathrm{M}$ manulang tahapan tersebut yaitu

1. Menetapkan alat pengukur (standard)

2. Mengadakan penilaian evaluate)

3. Mengadakan tindakan perbaikan (Badrudin, 2017) 
Setelah mendapatkan hasil dari upaya pengendalian Publikasi yang telah di upload di instagram, selanjutnya yaitu mengevaluasi. Pengelola aktif akun instagram Badan Nasional Pengelola Perbatasan akan melakukan evaluasi melalui weekly meeting yang dilakukan setiap hari jumat. Jadi setelah melakukan pertemuan tersebut tim humas BNPP mengevaluasi apa saja dari kekurangan konten yang sudah pernah di-upload sebelumnya, melalui insight tadi berupa komentar, likes, waktu upload yang harus konsisten dan jumlah Followers yang mengikuti akun instagram BNPP tersebut.

\section{SIMPULAN}

Humas yang berada pada biro Keuangan, Umum dan Humas Badan Nasional Pengelola Perbatasan sudah melakukan kegiatan publikasinya sesuai dengan teori P.O.A.C. Di mana semua kegiatan dilakukan, mulai dari planning, organizing, actuating, hingga controlling. Media yang digunakan dalam proses publikasi humas Badan Nasional Pengelola Perbatasan adalah media sosial Instagram dinilai sudah cukup efektif. Kegiatan dan informasi yang disebarluaskan melalui instagram berupa: hasil kerja pimpinan, rapat kebijakan lembaga, ucapan hari besar di Indonesia, Ucapan Hari raya, serta informasi mengenai wilayah perbatasan negera Indonesia. Konsistensi waktu meng-upload harus dilakukan agar semakin mengena informasi kepada masyarakat Indonesia.

Adapun hambatan yang terjadi dalam proses publikasi humas Badan Nasional Pengelola Perbatasan melalui media sosial instagram yaitu: Terdapat kekurangan Sumber Daya Manusia sebagai salah satu penunjang kegiatan publikasi humas BNPP yang merupakan indikator dari Perencanaan/Planning dalam proses publikasi Humas BNPP, selanjutnya dilihat dari sisi Organizing/ pengorganisasiannya salah satunya adalah teknologi, teknologi yang digunakan dalam proses pembuatan kontennya pun masih dinilai kurang karena dalam proses pembuatan publikasinya Staff humas BNPP masih menggunakan alat pribadi dalam melakukan pekerjaannya, lalu hambatan selanjutnya dan yang paling mencolok adalah dari sisi Actuating/ Pengarahan memberikan arahan melalui komunikasi vertikal, dalam proses pembuatan publikasinya, salah satu hambatannya itu adalah harus melewati beberapa approval/persetujuan beberapa pimpinan mengenai konten yang akan diunggah di instagram, sedangkan aktualitas dalam mengunggah informasi itu sangatlah penting.
Penambahan personil humas baik honorer maupun Pegawai Negeri Sipil yang diberikan oleh negara sebagai upaya memudahkan penugasan dan aktifitas dalam pembuatan publikasi humas, karena publikasi itu sangat penting yang kaitannya dengan informasi Lembaga. Personil juga harus direkrut dengan kualitas yang sesuai dengan kebutuhan yang diperlukan oleh lembaga dalam upaya meningkatkan pelayanan informasi publikasi khususnya di Instagram. Selanjutnya penambahan jumlah alat pendukung dalam proses pembuatan konten publikasi untuk disebarluaskan di media sosial, seperti penambahan komputer dan kamera DSLR yang sesuai degan kebutuhan alat publikasi humas BNPP agar tercapainya tujuan yang diinginkan. Serta sistem komunikasi yang tidak terlalu kaku/ komunikasi pada birokrasi yang tidak terlalu berbelit belit agar proses publikasi humas di Badan Nasional Pengelola Perbatasan berjalan dengan baik dan tepat waktu. Agar tercapainya tujuan bersama dalam mengembangkan informasi dan publikasi di lembaga tersebut.

\section{DAFTAR PUSTAKA}

Badrudin, P. D. (2017). DasarDasar Manajemen. Bandung: Alfabeta.

Fariani, S. R. (2013). Panduan Praktisi Public Relations. Jakarta: PT Elex Media Komputindo.

Hadria, M. J. (2017, November, 19). Masyarakat Harus Berperan Aktif Menjaga Perbatasan. (H. Kaltara, Pewawancara).

Kriyantono, R. (2016). Public Relations Writing; Teknik Produksi Media Public Relations dan Publisitas Korporat. Jakarta: Prenada Media.

Liliweri, P. D. (2011). Komunikasi Serba Ada Serba Makna. Jakarta: Kencana.

Mcquail, D. (2010). Teori Komunikasi Massa. Jakarta: Salemba Humanika.

Nasrullah, D. R. (2016). Media Siber Teori dan Riset. Jakarta: Prenamedia Group.

Perbatasan, B. N. (2019, Mei, 17). Peraturan BPK Perpres No 12 Tahun 2010. Diambil kembali dari Peraturan.bpk.go.id: https://peraturan. bpk.go.id/Home/Details/41036/perpres-no-12tahun-2010.

Ruslan, R. (2017). Metodologi Penelitian, Public Relations, dan Komunikasi. Jakarta: PT Rajagrafindo Persada.

Ruslan, R. (2018). Kampanye Public Relations. Jakarta: PT Rajagrafindo Persada. 
Sary, M. P. (2013). Media Massa Kontemporer. Depok: Prenadatama.

Social, W. A. (2019, Mei, 22). Jelajah Digital: Data dan Fakta Statistik Instagram. Diambil kembali dari Jelajah Digital: www.jelajahdigital.com/ datadanfaktastatistik/

Sugiyono. (2017). Metode Penelitian Kuantitatif Kualitatif. Bandung: Alfabeta.

Sukarna, D. (2011). Dasar-Dasar Manajemen. Bandung: Simbiosa Rekatama.

Suyanto, B. (2015). Metode Penelitian Sosial Berbagai Alternatif Pendekatan. Jakarta: Prenada Media. 